\title{
Quality of the Indoor Environment in Elderly Care Centers in Two Cities in Central Portugal: Viseu and Covilhã
}

\author{
Manuel Pinto ${ }^{1, * \mathbb{C}}$, João Lanzinha ${ }^{2} \mathbb{C}$, João Viegas ${ }^{3} \mathbb{C}$, Catarina Infante $^{4}$ and Tiago Freire ${ }^{5}$ \\ 1 School of Technology \& Management (ESTGV)—CONSTRUCT-LFC, Campus de Repeses, \\ 3504-510 Viseu, Portugal \\ 2 LABSED-UBIMedical, C-made-Centre of Materials and Building Technologies, Faculty of Engineering, \\ University of Beira Interior (UBI), Rua Marquês D’Ávila e Bolama, 6201-001 Covilhã, Portugal; \\ joao.lanzinha@ubi.pt \\ 3 National Laboratory for Civil Engineering (LNEC), Av. do Brasil, 101, 1700-066 Lisboa, Portugal; \\ jviegas@lnec.pt \\ 4 Master in Construction Engineering and Rehabilitation by the School of Technology \& \\ Management (ESTGV), Campus de Repeses, 3504-510 Viseu, Portugal; katarina.infante@gmail.com \\ 5 Master in Civil Engineering by University of Beira Interior (UBI), Rua Marquês D' Ávila e Bolama, \\ 6201-001 Covilhã, Portugal; tiago.sf6@gmail.com \\ * Correspondence: mpinto@estv.ipv.pt; Tel.: +351-232-480-500
}

Received: 22 August 2019; Accepted: 4 October 2019; Published: 9 October 2019

\begin{abstract}
Assessments of Indoor Environment Quality (IEQ) present a very significant challenge when analyses are undertaken mainly in buildings that include a particularly sensitive and vulnerable population, such as elderly people. In order to maintain an indoor environment that is adequate for occupants, it is necessary to comply with a set of requirements (for TVOC, the Portuguese threshold values) regarding concentrations of airborne pollutants and hygrothermal comfort conditions. This paper studies IEQ in compartments in 3 buildings in two cities in central Portugal, Viseu and Covilhã, which hold elderly care centers. The following environmental parameters were continuously recorded: air temperature, relative humidity, concentration of carbon dioxide, formaldehyde, and total volatile organic compounds and ventilation rates. An analysis of the obtained results was performed, taking recommended guidelines and threshold values into account, thus making it possible to evaluate the IEQ conditions and hygrothermal comfort in the selected indoor spaces. On the basis of the conclusions reached and the observed problems of hygrothermal comfort and indoor pollutants in the indoor spaces, a number of recommendations are proposed, specifically in terms of climate control, ventilation, and maintenance, in order to obtain an overall improvement of IEQ.
\end{abstract}

Keywords: Indoor Environment Quality (IEQ); Indoor Air Quality (IAQ); Elderly Care Centers (ECC)

\section{Introduction}

In developed countries, people spend more than $90 \%$ of their time indoors. Indoor environmental conditions are strongly related to health, well-being, and overall performance [1]. With people spending so much time inside buildings, the issue of Indoor Environment Quality (IEQ) becomes especially important; therefore, a set of functional requirements exist to provide increased occupant comfort. In addition to the need to satisfy occupants' comfort requirements, special attention must be paid to their health, since inadequate IEQ can negatively influence the occupants' quality of life, affecting their health status.

Although IEQ plays an important role in all types of buildings, particular consideration should be paid to Elderly Care Centers (ECC). The perception of the elderly as a risk group with regard 
to inadequate indoor environments, due mainly to the presence of pollutants in the indoor air, is essentially due to the fact that the elderly population's immune defenses are reduced, and many of them suffer from multiple chronic diseases [2]. Every building must therefore be designed, constructed, and maintained in order to provide adequate conditions of comfort [3].

With regard to the age pyramid in Portugal, approximately 19\% of the population is aged 65 or over. The Aging Index, i.e., the relationship between the number of people over 65 years of age and the number under the age of 14 , has shown an increasing trend in recent decades, mainly due to the decrease in the birth rate [4]. ECC have the potential to influence residents' lives socially, physically, and psychologically. Older people may be particularly at risk from the effects of air pollutants, even at low concentrations, because of their reduced immune defenses, as well as any underlying chronic diseases [5]. In addition, the results of some studies on thermal sensation indicate that older people prefer higher temperatures, in contrast with young adults [6-8]. In short, older people tend to have different thermal sensations and preferences compared to younger people. This, in turn, affects the way older people respond to changes in the thermal conditions around them $[9,10]$.

Studies in ECC are rare, perhaps because the premise that in these places, problems associated with the Indoor Air Quality (IAQ) are less important, due to the relatively low occupancy density. The most common studies in this field are related to comfort analyses [11]. However, in the last few years, some research on IAQ in premises for elderly people has been carried out. Walgraeve et al. [12] improved the sampling technique for VOC and applied their new technique in an assessment of IAQ in Flemish homes for the elderly. Almeida-Silva, Wolterbeek and Almeida [13] characterized the indoor air quality in ECC in order to assess residents' daily exposure to air pollutants, and to identify microenvironments with highest levels of impact on the elderly. Shao et al. [14] referred to the importance of air filtration as a means to mitigate reduced indoor air pollution levels.

More research is needed to better describe the IAQ where the elderly people are passing most of their time. This research is intended to contribute to that effort by providing information on elderly care premises in Portugal.

In order to maintain an indoor environment with acceptable air quality and levels of thermal comfort, it is necessary to comply with the reference levels for temperature and relative humidity $\left(T_{\text {int }}\right.$ e $\left.R H\right)$, with minimum values of air change rates $(\mathrm{ACH})$ and with maximum values of concentrations of indoor air pollutants. Portuguese regulations provide parameters for thermal considerations in buildings and IEQ, with the exception of $\mathrm{RH}$, for which European standardization provides recommendations.

Compliance with the reference levels and guideline and threshold values still requires a careful analysis of indoor air ventilation conditions. Indoor air ventilation plays a very important role, not only for IEQ, since the levels of pollutants are controlled through $\mathrm{ACH}$, but also in the conservation of the building, often preventing the development of pathologies related to humidity; these pathologies may cause the degradation of certain components of buildings which, in turn, leads to a decrease in IEQ for occupants. In buildings, the use of ventilation must also be adequate, so that thermal discomfort is avoided, but also to avoid excessive energy consumption.

In order to contribute to the deepening the knowledge on this subject, this article presents the results of measurements of indoor pollutants (carbon dioxide $\left(\mathrm{CO}_{2}\right)$, formaldehyde $\left(\mathrm{CH}_{2} \mathrm{O}\right)$, and total volatile organic compounds (TVOC)), as well as hygrothermal comfort conditions ( $\mathrm{T}_{\text {int }}, \mathrm{RH}$, and $\mathrm{ACH}$ ) in three ECC in the cities of Viseu and Covilhã, Portugal; see Figure $1[15,16]$. 


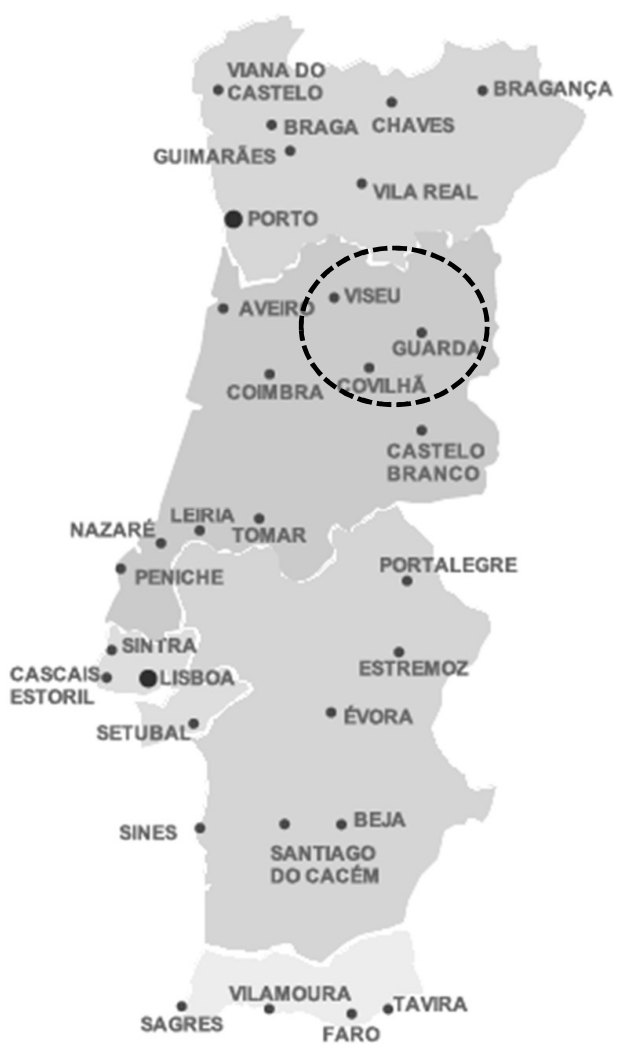

Figure 1. Map of Portugal showing the location of Viseu and Covilhã.

\section{Physical Characterization of the Studied Buildings and Compartments}

\subsection{City of Viseu}

Portuguese thermal regulations [17] indicate approximately 1700 heating degree days (base $18{ }^{\circ} \mathrm{C}$ ) for the town of Viseu, with an average elevation of $480 \mathrm{~m}$.

Two ECC with the following conditions were analyzed: (1) ECC 1: 7 rooms and 1 living room; (2) ECC 2: 5 rooms and 3 living room.

A physical characterization of the two buildings and some of the compartments studied is presented in Table 1, which shows that they were constructed at quite different times and in different locations, and feature dissimilar characteristics and technical installations. 
Table 1. Viseu: physical characterization of the buildings and some of the studied compartments.

\begin{tabular}{|c|c|c|c|c|c|c|c|}
\hline \multicolumn{4}{|c|}{ Buildings } & \multicolumn{4}{|c|}{ Rooms } \\
\hline & $\begin{array}{c}\text { Year of } \\
\text { Construction }\end{array}$ & $\begin{array}{c}\text { Climate } \\
\text { Control/Heating } \\
\text { System }\end{array}$ & $\begin{array}{l}\text { Ventilation } \\
\text { System }\end{array}$ & Designation & $\begin{array}{c}\text { Predominant } \\
\text { Orientation }\end{array}$ & Area $\left[\mathrm{m}^{2}\right]$ & $\begin{array}{c}\text { Usual Maximum } \\
\text { Occupancy/No. of } \\
\text { Residents }\end{array}$ \\
\hline \multirow{4}{*}{$\operatorname{ECC~} 1^{a}$} & \multirow{4}{*}{1994} & \multirow{4}{*}{$\begin{array}{l}\text { Intermittent heating } \\
\text { with water radiators }\end{array}$} & \multirow{4}{*}{ NV } & Room 1 & NW & 20.58 & 1 \\
\hline & & & & Room 2 & $\mathrm{SE}$ & 20.58 & 2 \\
\hline & & & & Room 3 & NW & 20.58 & 2 \\
\hline & & & & Living room & SE and SW & 257.32 & 25 \\
\hline \multirow{4}{*}{$\operatorname{ECC} 2^{b}$} & \multirow{4}{*}{1869} & \multirow{4}{*}{$\begin{array}{l}\text { Intermittent heating } \\
\text { with water radiators }\end{array}$} & \multirow{4}{*}{ NV } & Room 1 & $\mathrm{E}$ and NE & 24.61 & 3 \\
\hline & & & & Room 2 & W & 22.79 & 3 \\
\hline & & & & Living room 1 & W & 39.76 & 25 \\
\hline & & & & Living room $2^{c}$ & $\mathrm{~W}$ & 39.76 & 25 \\
\hline
\end{tabular}

Notes: ${ }^{a}$ Cleaning method: daily with aqueous solution; opening of windows during cleaning (unsystematic); ${ }^{b}$ Cleaning method: daily with aqueous solution; opening of windows during cleaning (unsystematic), outer walls uninsulated; ${ }^{c}$ Also serves as dining hall; the natural ventilation system (NV) is due to the natural air permeability of the envelope. There is not a properly designed, natural ventilation system 
According to the regulations in Portugal [18], the minimum area of living rooms should respect a ratio of $2 \mathrm{~m}^{2} /$ resident. In the case of ECC 2, this ratio is grossly disregarded.

Information about the interior cladding of the studied compartments, windows, and corresponding indoor and outdoor solar protection is presented in Table 2.

Table 2. Viseu: interior cladding, windows, and solar protection of the various compartments.

\begin{tabular}{|c|c|c|c|c|c|c|c|}
\hline \multirow{2}{*}{ Buildings } & \multirow{2}{*}{ Compartments } & \multirow{2}{*}{ Flooring } & \multirow{2}{*}{ Walls } & \multirow{2}{*}{ Ceiling } & \multicolumn{2}{|c|}{ Solar Protection } & \multirow{2}{*}{ Windows } \\
\hline & & & & & Interior & Exterior & \\
\hline \multirow[t]{2}{*}{ ECC 1} & $\begin{array}{l}\text { Room } 1 \\
\text { Room } 2 \\
\text { Room } 3\end{array}$ & $\begin{array}{l}\text { Wooden } \\
\text { parquet }\end{array}$ & \multirow[t]{2}{*}{ Plastered } & \multirow[t]{2}{*}{ Plastered } & Blackout curtains & Blinds & $\begin{array}{l}\text { Aluminum without } \\
\text { thermal brake; side hung } \\
\text { windows; double glazing }\end{array}$ \\
\hline & Living room & $\begin{array}{l}\text { Ceramic } \\
\text { tile }\end{array}$ & & & $\begin{array}{l}\text { Vertical blinds with } \\
\text { fabric slats }\end{array}$ & None & $\begin{array}{c}\text { Aluminum without } \\
\text { thermal brake; sliding } \\
\text { windows; double glazing }\end{array}$ \\
\hline \multirow[t]{2}{*}{ ECC 2} & $\begin{array}{c}\text { Room } 1 \\
\text { Room } 2 \\
\text { Living room } 1\end{array}$ & \multirow[t]{2}{*}{ Vinyl } & \multirow[t]{2}{*}{ Plastered } & \multirow[t]{2}{*}{ Plastered } & $\begin{array}{c}\text { Blackout curtains + } \\
\text { semi-opaque curtains }\end{array}$ & None & $\begin{array}{l}\text { Aluminum without } \\
\text { thermal brake; side hung }\end{array}$ \\
\hline & Living room 2 & & & & $\begin{array}{l}\text { Blackout fabric roller } \\
\text { blinds }\end{array}$ & & \\
\hline
\end{tabular}

\subsection{City of Covilhã}

Portuguese thermal regulations [17] indicate approximately 2000 heating degree days (base $18{ }^{\circ} \mathrm{C}$ ) for the town of Covilhã, with an average elevation of $750 \mathrm{~m}$.

A physical characterization of the studied building (ECC 3) and compartments is presented in Table 3. 
Table 3. Covilhã: physical characterization of the studied compartments.

\begin{tabular}{|c|c|c|c|c|c|c|c|}
\hline \multicolumn{4}{|c|}{ Building } & \multicolumn{4}{|c|}{ Compartments } \\
\hline & $\begin{array}{c}\text { Year of } \\
\text { Construction }\end{array}$ & $\begin{array}{c}\text { Climate } \\
\text { Control/Heating } \\
\text { System }\end{array}$ & Ventilation System & Designation & $\begin{array}{c}\text { Predominant } \\
\text { Orientation }\end{array}$ & Area $\left[\mathrm{m}^{2}\right]$ & $\begin{array}{l}\text { Usual Maximum } \\
\text { Occupancy/No. } \\
\text { of Residents }\end{array}$ \\
\hline \multirow{3}{*}{ ECC 3} & \multirow{3}{*}{2002} & \multirow{3}{*}{$\begin{array}{l}\text { Intermittent heating } \\
\text { with water radiators; } \\
\text { HVAC in living room } \\
\text { and dining hall }\end{array}$} & \multirow{3}{*}{$\begin{array}{c}\text { RR in the living room and dining hall: } \\
\text { MV-intermittent extraction } \\
\text { RR of the rooms: NV-opening of } \\
\text { windows }\end{array}$} & Living room & E & 134.00 & 25 \\
\hline & & & & Dining hall & E & 134.00 & 50 \\
\hline & & & & Triple room & SE & 33.92 & 3 \\
\hline
\end{tabular}

Note: Cleaning method-daily with aqueous solution; opening window while cleaning. 
Information about the interior cladding of the studied compartments, windows, and corresponding indoor and outdoor solar protection is presented in Table 4.

Table 4. Covilhã: interior cladding, windows, and solar protection in the various compartments.

\begin{tabular}{|c|c|c|c|c|c|c|c|}
\hline \multirow[b]{2}{*}{ Building } & \multirow[b]{2}{*}{ Compartments } & \multirow[b]{2}{*}{ Flooring } & \multirow[b]{2}{*}{ Walls } & \multicolumn{3}{|c|}{ Solar Protection } & \multirow[b]{2}{*}{ Windows } \\
\hline & & & & Ceiling & Interior & Exterior & \\
\hline \multirow[t]{2}{*}{ ECC 3} & Room & $\begin{array}{l}\text { Vinyl and } \\
\text { ceramic } \\
\text { tile }\end{array}$ & $\begin{array}{c}\text { Ceramic } \\
\text { tile }\end{array}$ & Plasterboard & $\begin{array}{l}\text { Slightly } \\
\text { transparent } \\
\text { curtains }\end{array}$ & Blinds & \multirow{2}{*}{$\begin{array}{c}\text { Aluminum } \\
\text { without thermal } \\
\text { brake; sliding } \\
\text { windows; double } \\
\text { glazing }\end{array}$} \\
\hline & $\begin{array}{c}\text { Living } \\
\text { room/dining } \\
\text { hall }\end{array}$ & Vinyl & & & $\begin{array}{c}\text { Semi-opaque } \\
\text { fabric roller blinds }\end{array}$ & None & \\
\hline
\end{tabular}

\section{Regulatory Requirements, Standards, and Experimental Conditions}

The protective thresholds for the considered physico-chemical pollutants are set out in Table 5.

Table 5. Parameters measured and reference concentrations.

\begin{tabular}{|c|c|c|c|c|c|c|}
\hline \multicolumn{2}{|c|}{ Parameters } & \multicolumn{2}{|c|}{$\begin{array}{l}\text { Protection Threshold in } \\
\text { New Buildings }\end{array}$} & \multirow{2}{*}{$\begin{array}{c}\text { Margin of } \\
\text { Tolerance }^{\mathbf{b}}\left(M T^{\mathrm{c}}\right) \\
{[\%]}\end{array}$} & \multicolumn{2}{|c|}{ Protection Threshold ${ }^{b}$} \\
\hline & & {$\left[\mathrm{mg} / \mathrm{m}^{3}\right]$} & [ppmv] & & {$\left[\mathrm{mg} / \mathrm{m}^{3}\right]$} & [ppmv] \\
\hline \multirow{3}{*}{$\begin{array}{l}\text { Physico-chemical } \\
\text { pollutants }\end{array}$} & TVOC [19] & 0.6 & $0.26^{\mathrm{a}}$ & 100 & 1.2 & $0.52^{\mathrm{a}}$ \\
\hline & $\mathrm{CH}_{2} \mathrm{O}[19]$ & 0.1 & 0.08 & & & \\
\hline & $\mathrm{CO}_{2}[19]$ & 2250 & 1250 & 30 & 2925 & 1625 \\
\hline \multicolumn{7}{|c|}{ Recommended/regulated level } \\
\hline \multirow{2}{*}{$\begin{array}{l}\text { Hygrothermal } \\
\text { comfort }\end{array}$} & $T[20-22]$ & \multicolumn{3}{|c|}{$20-25^{\circ} \mathrm{C}$} & & \\
\hline & $R H[22,23]$ & \multicolumn{3}{|c|}{$30-70 \%$} & & \\
\hline
\end{tabular}

Notes: ${ }^{a}$ Value obtained for the molar mass of isobutylene [24]; ${ }^{b}$ Margin of tolerance and protection threshold in existing buildings and new buildings without mechanical ventilation systems; for a mean of $8 \mathrm{~h}$; ${ }^{\mathrm{c}} \mathrm{MT}$ is the value added to "Protection threshold in new buildings" to get "Protection threshold in existing buildings and new buildings without mechanical ventilation", e.g., for TVOC: $0.6 \mathrm{mg} / \mathrm{m}^{3} \times 100 \%=1.2 \mathrm{mg} / \mathrm{m}^{3}$.

\section{Materials and Methods}

\subsection{Experimental Conditions in the City of Viseu}

Measurements of exterior temperature were obtained from [25]. Regarding the location chosen for placing the equipment inside the compartments, places were avoided, whenever possible, that could influence the measurements of the indoor environmental parameters, such as windows and climate control equipment. The $\mathrm{ACH}$ was assessed using the decay technique, using metabolic $\mathrm{CO}_{2}$ as a tracer gas (in post-occupancy periods), as described in ASTM E741 [26] and ASTM D6245 [27]. In Portugal, one of the supporting documents for testing is Technical Note TN-SCE-02, 2009 (ADENE-Portuguese energy agency), which, in Annex 3, allows the use of "Photonionization Detectors" (PID) as a monitoring method for TVOC and formaldehyde measurement [24]. Thus, such equipment was used in both cities.

The measurements of pollutants were carried out continuously in the rooms. They were performed during the period of occupancy [7:30 a.m. to 7:30 p.m.] in the living rooms. In view of the available equipment, only one point of analysis of the various parameters in each compartment was considered [24].

Two trials were conducted: the first in winter, i.e., between December 2015 and January 2016, and the second in spring, i.e., between March and April 2016.

Table 6 presents the parameters, measuring instruments, and the main conditions of measurement. 
Table 6. Viseu: parameters, technical characteristics of the equipment used, and conditions of measurement.

\begin{tabular}{|c|c|c|c|c|c|}
\hline Parameters & Instrument & Accuracy & Measurement Range & $\begin{array}{l}\text { Duration of } \\
\text { Measurement }\end{array}$ & $\begin{array}{l}\text { Maximum } \\
\text { Measurement } \\
\text { Period }^{\mathrm{a}}\end{array}$ \\
\hline $\begin{array}{c}\mathrm{T} \\
\mathrm{RH} \\
\mathrm{CO}_{2}\end{array}$ & $\begin{array}{l}\text { Telaire } 7001 \\
\text { with data } \\
\text { logger U12-013 } \\
\text { coupled to } \\
\text { record data }\end{array}$ & $\begin{array}{c} \pm 0.35^{\circ} \mathrm{C}\left(0 \text { to } 50{ }^{\circ} \mathrm{C}\right) \\
\pm 2.5 \%(10 \text { to } 90 \%) \\
\pm 50 \mathrm{ppm}\end{array}$ & $\begin{array}{c}-20 \text { to } 70^{\circ} \mathrm{C} ; \\
5 \text { to } 95 \% ; \\
0 \text { to } 10,000 \mathrm{ppm} \text { on the } \\
\text { display; } \\
0 \text { to } 4000 \mathrm{ppm} \text { on the } \\
\text { external connection }\end{array}$ & 1 min & 4 days \\
\hline $\begin{array}{c}T \\
R H\end{array}$ & $\begin{array}{l}\text { Data logger } \\
\text { U12-012 }\end{array}$ & $\begin{array}{c} \pm 0.35^{\circ} \mathrm{C}\left(0 \text { to } 50{ }^{\circ} \mathrm{C}\right) \\
\pm 2.5 \%(10 \text { to } 90 \%) \\
\pm 0.9^{\circ} \mathrm{C}\left(40 \text { to } 60^{\circ} \mathrm{C}\right)\end{array}$ & $\begin{array}{l}-20 \text { to } 70^{\circ} \mathrm{C} \\
5 \text { to } 95 \%\end{array}$ & $1 \mathrm{~min}$ & 4 days \\
\hline $\begin{array}{c}T \\
\text { RH } \\
\mathrm{CO}_{2}\end{array}$ & $\begin{array}{l}\text { Fluke } 975 \\
\text { AirMeter }\end{array}$ & $\begin{array}{c} \pm 0.5^{\circ} \mathrm{C}\left(5 \text { to } 40{ }^{\circ} \mathrm{C}\right) \\
\pm 1.1^{\circ} \mathrm{C}\left(-20 \text { to } 5^{\circ} \mathrm{C}\right) \\
\pm 2 \%(10 \text { to } 90 \%) \\
2.75 \%+75 \mathrm{ppm}\end{array}$ & $\begin{array}{c}-20 \text { to } 60^{\circ} \mathrm{C} ; \\
10 \text { to } 90 \% ; \\
0 \text { to } 5000 \mathrm{ppm}\end{array}$ & $1 \mathrm{~min}$ & 4 days \\
\hline TVOC & $\begin{array}{l}\text { PhoCheck Tiger } \\
\text { (PID) }\end{array}$ & $\begin{array}{c} \pm 5 \% \text { of the display reading } \\
\pm \text { one digit }\end{array}$ & $1 \mathrm{ppb}$ to $20,000 \mathrm{ppm}$ & $30 \mathrm{~s}$ & $10 \mathrm{~h}$ \\
\hline
\end{tabular}

Note: ${ }^{\text {a: }}$ During an experimental campaign, there are several measurement periods (e.g., depending on the equipment's memory capacity or the experimental conditions); the "Maximum measurement period" is the longest measurement period.

\subsection{Experimental Conditions in the City of Covilhã}

Outdoor temperature measurements were obtained from a meteorological station at the University of Beira Interior (UBI), located at approximately $680 \mathrm{~m}$ altitude. Regarding the location chosen to place instruments inside the compartments and to assess the $\mathrm{ACH}$, the criteria already presented were followed.

The measurements of the pollutants were performed continuously; each reading was measured over a minimum period of $5 \mathrm{~min}$ [24]. Due to the limitations of the instruments, the measurements of formaldehyde were punctual, although a maximum of 3 measurements, taken at 5 min intervals, was obtained. The first trial took place in February and June 2014, and the second in April and May 2015.

The minimum number of analysis points for the various indoor air quality parameters to be measured was calculated by applying the following expression to the total area of the compartment, rounding up to the unit [24]:

$$
N_{\mathrm{i}}=0.15 \times A_{i}^{0.5}
$$

where $N_{\mathrm{i}}$ is the number of measurement points in zone $i$ and $A_{\mathrm{i}}$ is the area of zone $i\left(\mathrm{~m}^{2}\right)$.

Table 7 shows the minimum number of measurement points calculated.

Table 7. Minimum number of measurement points per compartment.

\begin{tabular}{cccccc}
\hline Building & Compartment & $\begin{array}{c}\text { Area } \\
{\left[\mathbf{m}^{\mathbf{2}}\right]}\end{array}$ & $\begin{array}{c}\text { Volume } \\
{\left[\mathbf{m}^{\mathbf{3}}\right]}\end{array}$ & $\begin{array}{c}\text { Minimum Number } \\
\text { of Measuring Points }\end{array}$ & $\begin{array}{c}\text { Number of } \\
\text { Measured Points }\end{array}$ \\
\hline \multirow{3}{*}{ ECC 3 } & Living room & 134.00 & 375.2 & 2 & 3 \\
\cline { 2 - 6 } & Canteen & 134.00 & 375.2 & 2 & 3 \\
\cline { 2 - 6 } & Triple room & 33.92 & 95.0 & 1 & 1 \\
\hline
\end{tabular}

Table 8 shows the parameters, measuring instruments, and the main conditions of measurement. 
Table 8. Covilhã: parameters, technical characteristics of the equipment used, and conditions of measurement.

\begin{tabular}{|c|c|c|c|c|c|}
\hline Parameters & Instruments & Accuracy & $\begin{array}{l}\text { Measuring } \\
\text { Range }\end{array}$ & $\begin{array}{l}\text { Measuring } \\
\text { Interval }^{\mathrm{a}}\end{array}$ & Measuring Period $^{b}$ \\
\hline $\mathrm{CH}_{2} \mathrm{O}$ & $\begin{array}{c}\text { Formaldemeter } \\
\text { htV-M }\end{array}$ & $\pm 10 \%$ & $0-10 \mathrm{ppm}$ & Punctual $^{\mathrm{a}}$ & $\begin{array}{l}3 \text { measurements } \\
\text { spaced every } 5 \mathrm{~min}\end{array}$ \\
\hline $\mathrm{CO}_{2}$ & $\begin{array}{c}\text { TSI Velocicalc } \\
9565-\mathrm{P} \\
\text { (986 probe) }\end{array}$ & $\begin{array}{c} \pm 3 \% \text { or } 50 \text { ppm, } \\
\text { whichever is greater }\end{array}$ & $0-5000$ ppm & $15 \mathrm{~s}$ & $\begin{array}{l}3 \text { measurements } \\
5 \text { min each }\end{array}$ \\
\hline TVOC & $\begin{array}{l}\text { TSI Velocicalc } \\
\text { 9565-P } \\
\text { (986 probe; } \\
\text { PID) }\end{array}$ & $\begin{array}{l}\quad \pm 20 \% \\
\text { (according to the } \\
\text { representative's } \\
\text { information) }\end{array}$ & $\begin{array}{l}0.01-20 \mathrm{ppm}, \\
\text { isobutylene }\end{array}$ & $15 \mathrm{~s}$ & $\begin{array}{l}3 \text { measurements } \\
5 \text { min each }\end{array}$ \\
\hline $\begin{array}{c}T \\
R H\end{array}$ & Extech RH520 & $\begin{array}{c} \pm 1.0^{\circ} \mathrm{C} \\
\pm 3.0 \%\end{array}$ & $\begin{array}{c}-28-60{ }^{\circ} \mathrm{C} \\
10-95 \%\end{array}$ & $1 \mathrm{~min}$ & 15 to 30 days \\
\hline
\end{tabular}

Notes: " "Measuring interval" is the time between two successive measurements. The formaldehyde measuring interval spot (punctual) is an isolated (instantaneous) measurement; b "Measuring period" is the set of all "Measuring intervals".

In all presented results (cities of Viseu and Covilhã), the calculated mean $(\mu)$ refers to the arithmetic mean.

\section{Presentation and Critical Analysis of Results}

In the analysis of the results, according to Table 5, the following situations of discomfort and levels of pollutants were considered inadequate and excessive (the ECC analyzed were considered to be existing buildings [19]): (1) Percentage of time analyzed greater than or equal to $20 \%$ in the case of $T_{\text {int }}$ outside the range $\left[20^{\circ} \mathrm{C} ; 25^{\circ} \mathrm{C}\right.$ ] and $R H_{\text {int }}$ outside the range [30\%; 70\%]; (2) Threshold of $\mathrm{CO}_{2}$ protection exceeded (1625 ppm for a mean of $8 \mathrm{~h}$ ); (3) Threshold of TVOC protection exceeded $\left(0.52 \mathrm{ppm}\right.$ for a mean of $8 \mathrm{~h}$ ); (4) Threshold of $\mathrm{CH}_{2} \mathrm{O}$ protection exceeded ( $0.08 \mathrm{ppm}$ for a mean of $8 \mathrm{~h}$ ).

As for $T_{\text {int }}$ and $R H_{\text {int }}$, this "excessive" percentage is considered to be reasonable in assessments of indoor environments, since existing regulations are relatively recent, and the buildings have envelope and HVAC systems that are mostly unprepared for the new, very high standards. Moreover, if the percentage defined is too small (e.g., $<5-10 \%$ ), implementing climate control in these spaces would become quite expensive.

\subsection{Viseu}

\subsubsection{ECC 1}

In the compartments of ECC 1, in both trials, approximately constant temperatures and relative humidity were recorded; they were within the recommended values $\left(20^{\circ} \mathrm{C}-25{ }^{\circ} \mathrm{C} ; 30-70 \%\right)$. This may be because the building in question is recent, with improved systems relative to the ECC 2 . An example of this is the existence of double-glazed windows with aluminum frames, without thermal brakes, in all of the compartments, as well as the existence of thermal insulation in the envelope of the building.

Table 9 shows a statistical analysis of indoor pollutants $\left(\mathrm{CO}_{2}\right.$ and TVOC), recorded in the compartments of ECC 1 during the second trial. 
Table 9. Statistical analysis of the pollutants recorded in ECC 1 compartments: $2^{\text {nd }}$ trial (21 to 25 March).

\begin{tabular}{|c|c|c|c|c|c|c|}
\hline \multirow[b]{2}{*}{ Compartment } & \multicolumn{3}{|c|}{$\begin{array}{c}\mathrm{CO}_{2} \\
{[\mathrm{ppm}]}\end{array}$} & \multicolumn{3}{|c|}{$\begin{array}{l}\text { TVOC } \\
\text { [ppm] }\end{array}$} \\
\hline & Max & $\mu \pm \sigma$ & $\begin{array}{c}\text { Maximum of } 8 \mathrm{~h} \\
\text { Means }\end{array}$ & $\operatorname{Max}$ & $\mu \pm \sigma$ & $\begin{array}{l}\text { Maximum of } 8 \mathrm{~h} \\
\text { Means }(n=480)\end{array}$ \\
\hline Room 1 & 1272 & $78 \pm 83$ & 888 & 0.86 & $0.05 \pm 0.06$ & 0.05 \\
\hline Room 2 & 1343 & $710 \pm 101$ & 840 & 2.60 & $0.20 \pm 0.25$ & 0.24 \\
\hline Room 3 & 1324 & $705 \pm 245$ & 850 & 0.32 & $0.07 \pm 0.06$ & 0.08 \\
\hline Living room & 2538 & $1562 \pm 335$ & 1861 & 0.08 & $0.04 \pm 0.02$ & 0.04 \\
\hline
\end{tabular}

According to the results presented in Table 9 and shown in Figure 2, we conclude that: (1) The living room presented a maximum mean value of $\mathrm{CO}_{2}$ which is above the protection threshold. From Figure 2, we can see that the maximum peaks of pollutants occurred during the period of the room's occupancy, mostly during the afternoon. We can also see that outside the period of occupancy, the values of $\mathrm{CO}_{2}$ remained below the regulatory limits. The high values may therefore be due to the high density of occupancy of the living room, reduced $\mathrm{ACH}$, or even to possible combustion processes, since the kitchen and the dining hall are located in the vicinity of the living room; (2) TVOC concentrations were not of concern in any of the analyzed compartments. The standard deviation values of the TVOC of the rooms were high, and we may conclude that the most influential parameters (type of activities and $\mathrm{ACH}$ ) vary quite a bit during occupancy.

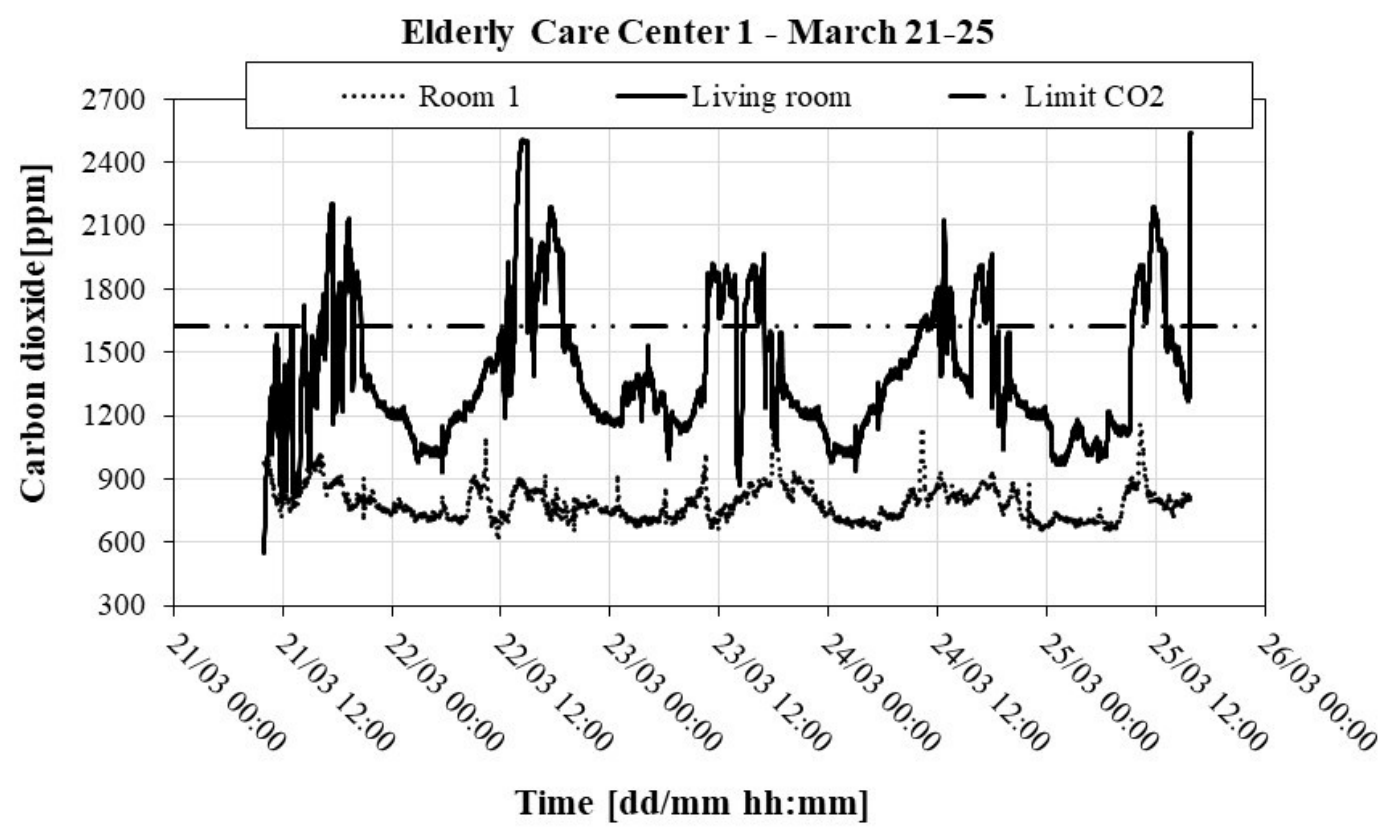

Figure 2. Recording of $\mathrm{CO}_{2}$ in room 1 and the living room of ECC 1: $2^{\text {nd }}$ trial (21 to $\left.25 \mathrm{March}\right)$.

\subsubsection{ECC $2-1^{\text {st }}$ Trial}

Table 10 shows a statistical analysis of the temperatures and relative humidity recorded in the compartments of ECC 2 during the first trial. We may essentially conclude that: (1) The rooms analyzed show an excessive percentage of time in which the indoor temperatures are lower than prescribed 
(recommended range: $20^{\circ} \mathrm{C}$ to $25^{\circ} \mathrm{C}$ ). However, comparing these with the mean temperatures, we can state that temperatures which are uncomfortably low are only slightly lower than $20^{\circ} \mathrm{C}$; (2) The temperatures in the living rooms were found to be within the recommended guidelines. These conditions of thermal comfort may reflect better climate control and the fact that these compartments had a high occupancy density throughout the day; (3) The living rooms had reasonable mean $R H$ values; (4) The rooms had excessive percentages of time where the $R H$ values registered were higher than the recommended maximum limit.

Table 10. Statistical analysis of the hygrothermal parameters recorded in compartments of ECC 2: $1^{\text {st }}$ trial (4 to 8 January).

\begin{tabular}{|c|c|c|c|c|c|c|c|c|}
\hline \multirow[b]{2}{*}{ Compartment } & \multicolumn{3}{|c|}{$\begin{array}{l}T_{\text {int }} \\
{\left[{ }^{\circ} \mathrm{C}\right]}\end{array}$} & \multicolumn{3}{|c|}{$\begin{array}{c}R H_{\text {int }} \\
{[\%]}\end{array}$} & \multirow[t]{2}{*}{$\begin{array}{l}T_{\text {ext }} \\
{\left[{ }^{\circ} \mathrm{C}\right]}\end{array}$} & \multirow[t]{2}{*}{$\begin{array}{c}\Delta T \\
{\left[{ }^{\circ} \mathrm{C}\right]}\end{array}$} \\
\hline & $\mu \pm \sigma$ & Perc $\leq 20^{\circ} \mathrm{C}$ & Perc $\geq 25^{\circ} \mathrm{C}$ & $\mu \pm \sigma$ & Perc $\leq 30 \%$ & Perc $\geq 70 \%$ & & \\
\hline Room 1 & $19.6 \pm 0.9$ & 64 & 0 & $73 \pm 1$ & 0 & 99 & & 9.7 \\
\hline Room 2 & $19.9 \pm 0.8$ & 55 & 0 & $70 \pm 2$ & 0 & 51 & & 10.0 \\
\hline Room 3 & $20.4 \pm 0.8$ & 31 & 0 & $68 \pm 2$ & 0 & 21 & $9.9 \pm 2.6$ & 10.5 \\
\hline Room 4 & $19.5 \pm 0.8$ & 74 & 0 & $69 \pm 3$ & 0 & 49 & & 9.6 \\
\hline Room 5 & $19.7 \pm 0.7$ & 63 & 0 & $69 \pm 3$ & 0 & 46 & & 9.8 \\
\hline Living room 1 & $24.4 \pm 0.3$ & 0 & 3 & $52 \pm 4$ & 0 & 0 & & 14.3 \\
\hline Living room 2 & $23.1 \pm 0.8$ & 0 & 0 & $59 \pm 2$ & 0 & 0 & $10.1 \pm 2.5$ & 13.0 \\
\hline Living room 3 & $22.4 \pm 0.5$ & 0 & 0 & $57 \pm 5$ & 0 & 0 & & 12.3 \\
\hline
\end{tabular}

Notes: (1) The measurements were continuous in the rooms, while in the living room, the measurement refers to the normal period of occupancy: from 7.30 a.m. to 7.30 p.m.; (2) $\Delta T$ is the difference between the means of $T_{\text {int }}$ and $T_{\text {ext }}$; (3) Perc is "Percentage of time that exceeds a certain value"; see Nomenclature.

The thermal comfort of rooms 1 and 2 and living rooms 1 and 2 of ECC 2 was assessed using the adaptive model proposed by LNEC [28], as shown in Figure 3.

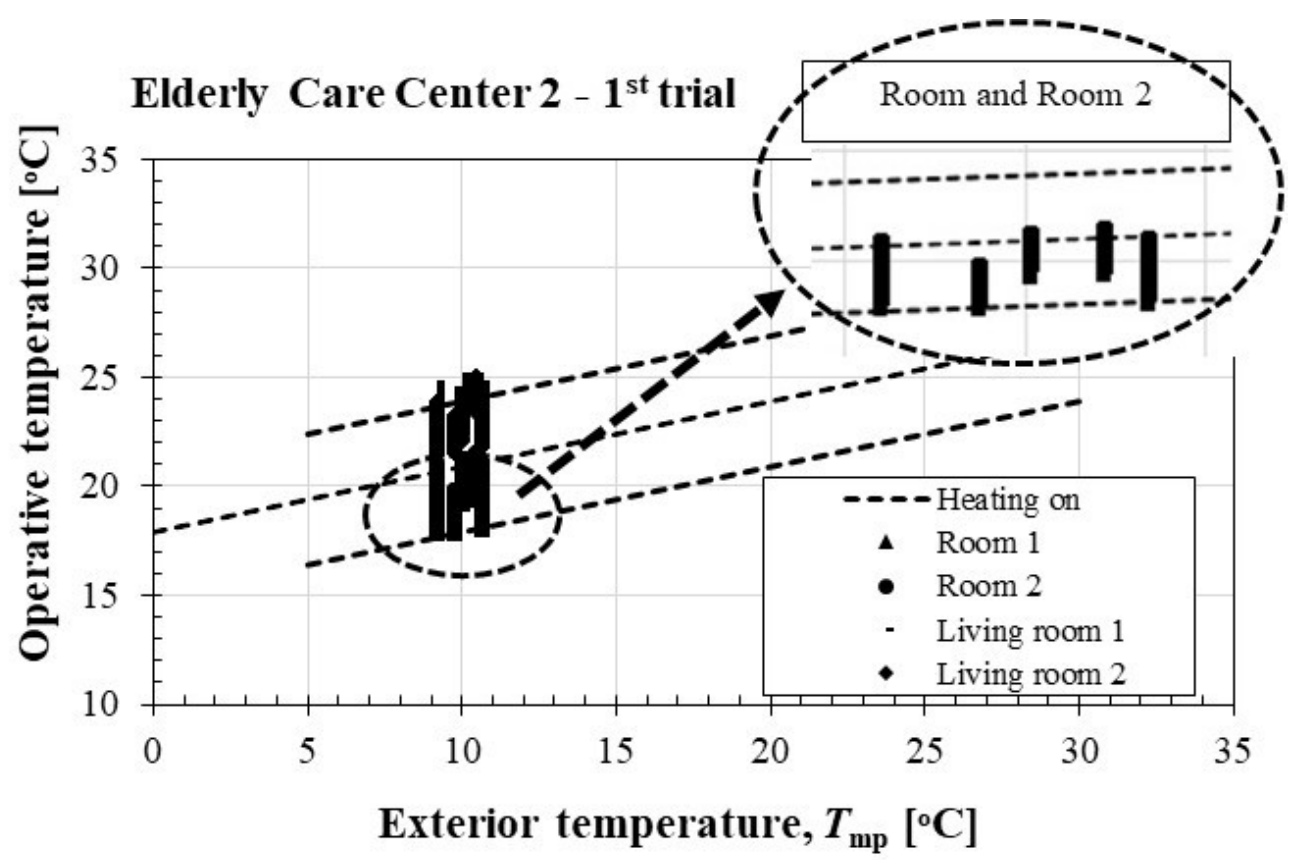

Figure 3. Assessment of thermal comfort by the adaptive method of the LNEC in ECC 2: $1^{\text {st }}$ trial.

The "Operative temperature" can be calculated, with good approximation, considering the arithmetic mean between $T_{\text {int }}$ and $T_{\mathrm{mp}}$ (ASHRAE 55, 2004 [29]; EN ISO 7730, 2005 [30]).

Considering the use of active air conditioning (central heating with water radiators), the results revealed the existence of a thermally comfortable environment in practically all compartments, with the temperature data within the established "comfortable" guideline values. 
The statistical analysis of the indoor pollutants $\left(\mathrm{CO}_{2}\right.$ and TVOC) recorded in the compartments of ECC 2 during the first trial showed that: (1) Room 1 and living room 2 had high mean $\mathrm{CO}_{2}$ values. Nevertheless, none of the compartments analyzed presented mean TVOC values of concern; (2) With the exception of living room 1, all the compartments analyzed had a maximum mean value of $\mathrm{CO}_{2}$ which was above the protection threshold.

Table 11 presents the ACH of living rooms 1 and 2 in ECC 2.

Table 11. Ventilation rates of living rooms 1 and 2 in ECC 2: $1^{\text {st }}$ trial.

\begin{tabular}{lccccc}
\hline Compartment & $\begin{array}{c}\mathbf{A C H}_{\mathbf{a v}} \\
{\left[\mathbf{h}^{-1}\right]^{\mathbf{a}}}\end{array}$ & $\begin{array}{c}\boldsymbol{q}_{\mathrm{RECS}} \\
{\left[\mathbf{m}^{\mathbf{3}} /(\mathbf{h} \text {-person) }]^{\mathbf{b}}\right.}\end{array}$ & $\begin{array}{c}\text { Volume } \\
{\left[\mathbf{m}^{\mathbf{3}}\right]}\end{array}$ & $\begin{array}{c}\text { Maximum Usual } \\
\text { Occupancy-Number } \\
\text { of Residents }\end{array}$ & $\begin{array}{c}\mathrm{ACH}_{\mathrm{RECS}} \\
{\left[\mathbf{h}^{-1}\right]^{\mathbf{c}}}\end{array}$ \\
\hline Living room 1 & 0.48 & 24 & 117.69 & 25 & 5.10 \\
Living room 2 & 0.39 & 24 & 71.97 & 20 & 6.67 \\
\hline
\end{tabular}

Notes: ${ }^{a}$ To determine mean $\mathrm{ACH}$ by the $\mathrm{CO}_{2}$ decay method, a total of 5 trials were used for living room 1 and 4 for living room 2; ${ }^{\mathrm{b}}$ Air flow rates were obtained in [19]; $q_{\text {RECS }}$ means "Air flow rate", obtained in accordance with "Ordinance 353-A/2013" (see Nomenclature); ${ }^{c} \mathrm{ACH}_{\mathrm{RECS}}$ means "Air change rate", obtained in accordance with "Ordinance 353-A/2013" (see Nomenclature).

From the results presented, we may conclude that both living rooms analyzed had poor ACH (well below the regulatory $\mathrm{ACH}$ in both cases).

\subsection{Covilhã}

\subsection{1. $1^{\text {st }}$ Trial}

Table 12 shows the results of the pollutant measurements.

Table 12. Statistical data of the pollutants recorded in ECC 3 compartments: $1^{\text {st }}$ trial (March).

\begin{tabular}{ccccc}
\hline Compartment & $\begin{array}{c}\mathrm{CO}_{2} \\
{[\mathbf{p p m}]_{\mathbf{M a x}} \mathbf{b}}\end{array}$ & $\begin{array}{c}\text { TVOC } \\
{[\mathbf{p p m}]_{\mathbf{M a x}} \mathbf{b}}\end{array}$ & $\begin{array}{c}\mathrm{CH}_{\mathbf{2}} \mathbf{O} \\
{[\mathbf{p p m}]_{\mathbf{M a x}} \mathbf{b}}\end{array}$ \\
\hline \multirow{2}{*}{ ECC 3 } & Living room & 889 & 0.25 & 0.07 \\
& Dining hall & $694^{\mathrm{a}}$ & 0.19 & 0.06 \\
& Triple room & $684^{\mathrm{a}}$ & 0.33 & 0.13 \\
\hline
\end{tabular}

Notes: ${ }^{a}$ measurement obtained outside hours of use; ${ }^{b}$ maximum value of 3 means of 5 min each.

With respect to the values presented, and taking the measurement period into account $(\approx 5 \mathrm{~min})$, we may conclude that the triple room presented elevated levels of formaldehyde. No potential source was identified; therefore, we speculate that this may be due to the wall coverings or other materials used. These values require further investigation.

The hygrothermal comfort conditions are shown in Figure 4 and Table 13. 


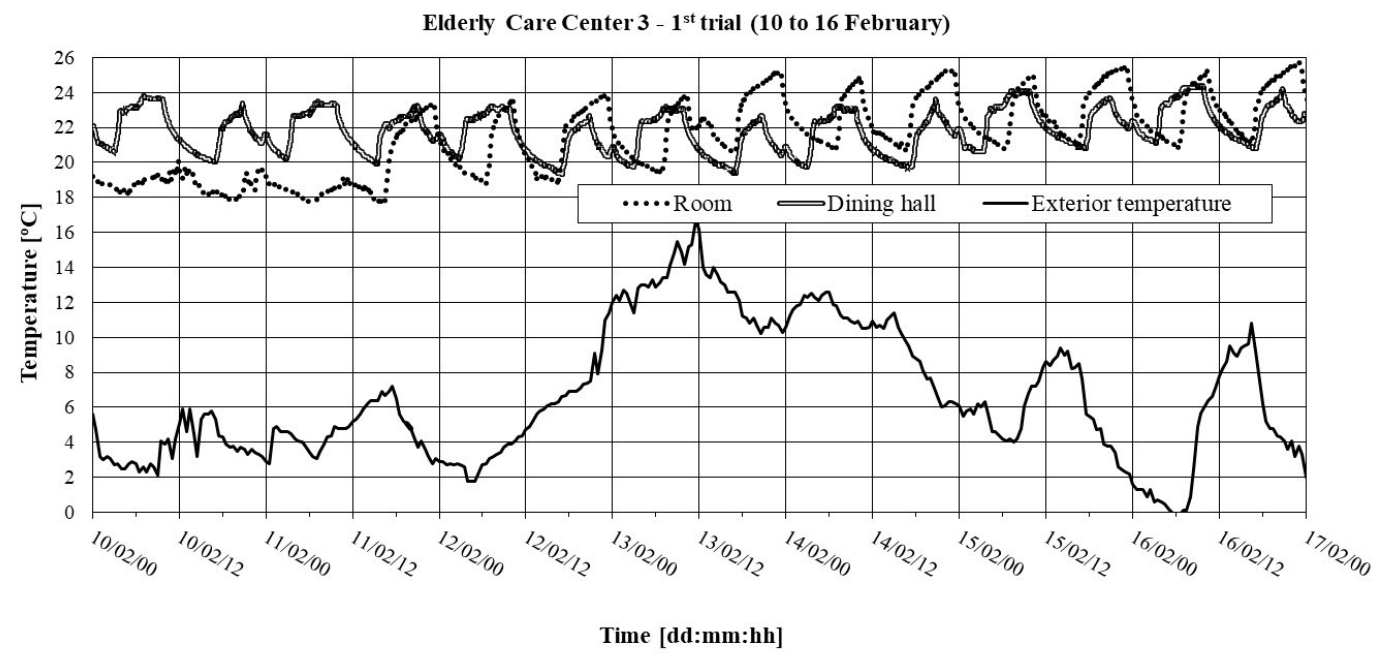

Figure 4. Interior temperature in ECC 3: $1^{\text {st }}$ trial (10 to 16 February).

Table 13. Statistical analysis of hygrothermal parameters recorded in compartments of ECC 3: $1^{\text {st }}$ trial (February-March).

\begin{tabular}{|c|c|c|c|c|c|c|c|c|c|}
\hline & & & $\begin{array}{l}T_{\text {int }} \\
{\left[{ }^{\circ} \mathbf{C}\right]}\end{array}$ & & & $\begin{array}{c}R H_{\text {int }} \\
{[\%]}\end{array}$ & & $\begin{array}{l}T_{\text {ext }} \\
{\left[{ }^{\circ} \mathrm{C}\right]}\end{array}$ & $\begin{array}{c}\Delta T \\
{\left[{ }^{\circ} \mathrm{C}\right]}\end{array}$ \\
\hline & Compartment & $\mu \pm \sigma$ & Perc $\leq 20^{\circ} \mathrm{C}$ & Perc $\geq 25^{\circ} \mathrm{C}$ & $\mu \pm \sigma$ & Perc $\leq \mathbf{3 0} \%$ & Perc $\geq 70 \%$ & $\mu \pm \sigma$ & \\
\hline \multirow{3}{*}{ ECC 3} & Living room & $23.8 \pm 1.2$ & 7 & 16 & $44 \pm 5$ & 0 & 0 & $10.4 \pm 4.9$ & 13.4 \\
\hline & Dining hall & $22.7 \pm 1.3$ & 2 & 1 & $46 \pm 5$ & 0 & 0 & $7.4 \pm 3.3$ & 15.3 \\
\hline & Triple room & $22.0 \pm 2.3$ & 26 & 11 & $47 \pm 7$ & 1 & 0 & $7.4 \pm 3.3$ & 14.6 \\
\hline
\end{tabular}

It should be noted that in the ECC 3, the measurement in the living room was not performed simultaneously with the other two compartments, which is why this compartment is not shown in Figure 4.

An analysis of Figure 4 and Table 13 leads us to conclude that: (1) A cyclical variation of the interior temperature is noticeable. This variation is due to the heating schedule, i.e., heating periods start at 6.00 a.m. and 6.00 p.m.; (2) The compartments present reasonable mean values for the mean indoor temperature, reflecting, in particular, the existing climate control/heating systems; (3) There is an excessive percentage of time with temperatures below regulations in the room (perhaps reflecting the opening of windows while cleaning); (4) There was some time in the two compartments in which the temperatures were above those prescribed by regulation. This may be due to their orientation (SE and E) or insufficient sun protection with regards to the windows, as in the living room; (5) The compartments do not present levels of RH of concern.

\subsection{2. $2^{\text {nd }}$ Trial}

The $2^{\text {nd }}$ trial took place in the spring of 2015, continuously recording concentrations of $\mathrm{CO}_{2}$ and TVOC only at one point, with a 2-min time interval and a "Maximum measurement period" between 1 and 8 days. Table 14 shows the results of the measurements of pollutants and ACH.

Table 14. Statistical analysis of the pollutants recorded in ECC 3 compartments and calculation of ACH: $2^{\text {nd }}$ trial (April-May).

\begin{tabular}{ccccccccc}
\hline & \multicolumn{2}{c}{$\begin{array}{c}\mathrm{CO}_{2} \\
{[\mathrm{ppm}]}\end{array}$} & $\begin{array}{c}\mathrm{ACH}_{\mathbf{a v}} \\
{\left[\mathbf{h}^{-1}\right]}\end{array}$ & $\begin{array}{c}\mathrm{ACH}_{\mathrm{RECS}} \\
{\left[\mathbf{h}^{-1}\right]}\end{array}$ & \multicolumn{2}{c}{$\begin{array}{c}\text { TVOC } \\
{[\mathbf{p p m}]}\end{array}$} & $\begin{array}{c}\mathrm{CH}_{2} \mathbf{O} \\
{[\mathbf{p p m}]_{\text {Max }}}\end{array}$ \\
\hline \multirow{2}{*}{ ECC 3 } & Compartment & $\mu \pm \sigma$ & Perc $\geq \mathbf{1 6 2 5}$ & & & $\mu \pm \sigma$ & Perc $\geq \mathbf{0 . 5 2}$ & $\mu$ \\
& Living room & $723 \pm 253$ & 0.8 & 0.22 & 1.6 & $0.04 \pm 0.09$ & 6.7 & 0.09 \\
& Triple room & $890 \pm 335$ & 0.0 & 0.81 & 0.5 & $0.17 \pm 0.15$ & 7.3 & 0.04 \\
\hline
\end{tabular}

Notes: (1) The measurements in the living room refer to the usual period of occupancy: 6.30 a.m. to 6.30 p.m.; (2) A total of 8 trials were conducted in the living room, and 5 in the triple room, to determine the mean $\mathrm{ACH}_{\text {by }}$ the $\mathrm{CO}_{2}$ decay method. 
Figures 5 and 6 show the temporal evolution of $\mathrm{CO}_{2}$ and TVOC. The initial points of the $\mathrm{CO}_{2}$ decay method are shown; they were used to determine the $\mathrm{ACH}$ through the decay technique. Points with maximum levels of TVOC are also shown.

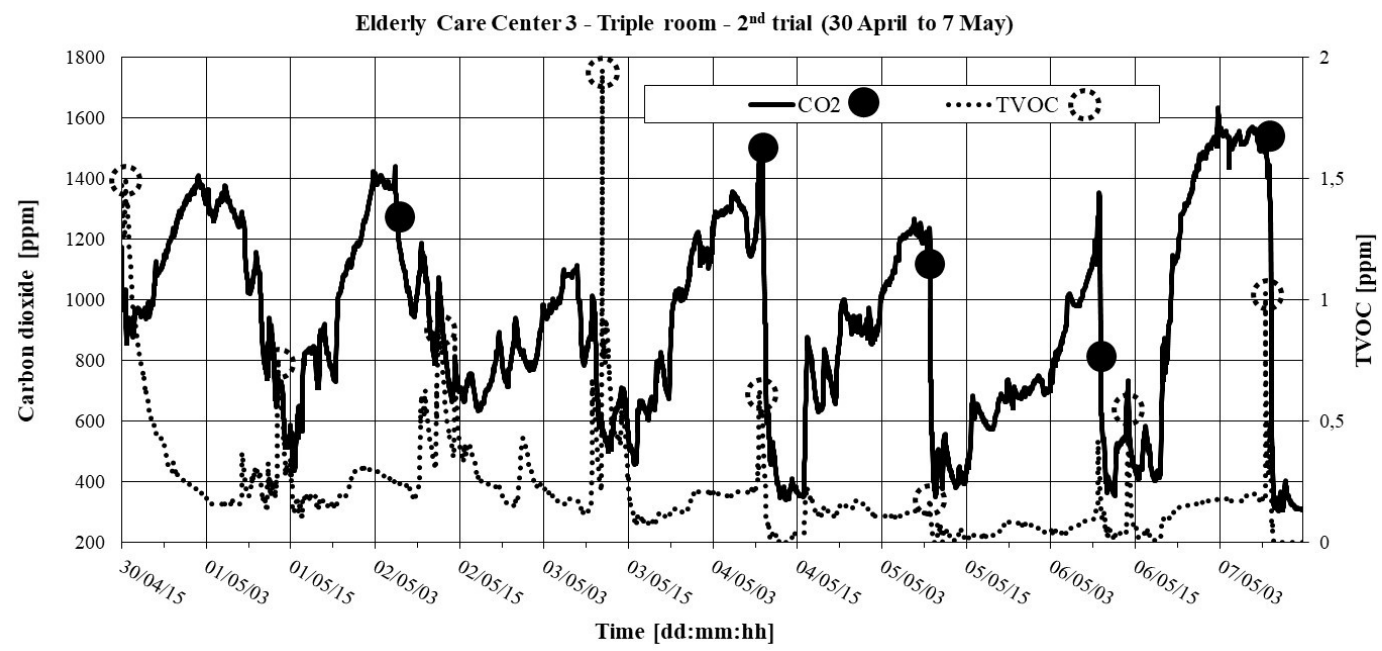

Figure 5. $\mathrm{CO}_{2}$ and TVOC in the triple room in ECC 3: $2^{\text {nd }}$ trial (30 April to 7 May).

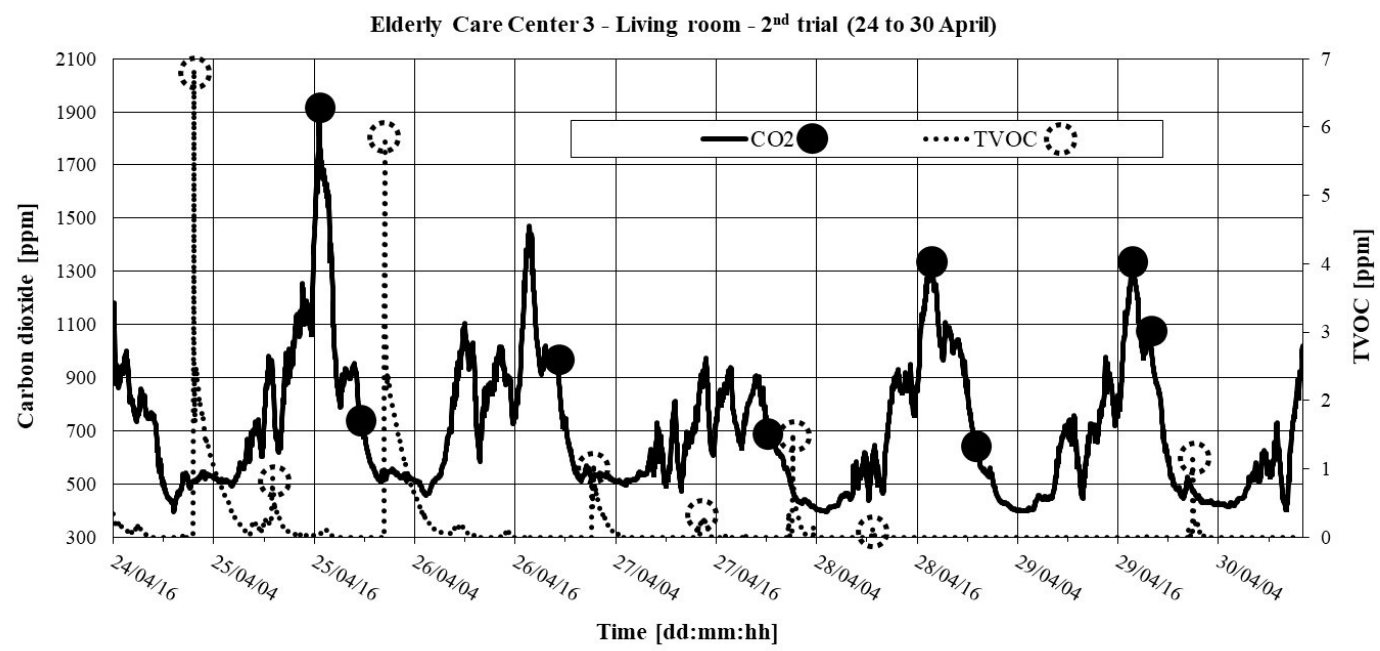

Figure 6. $\mathrm{CO}_{2}$ and TVOC in the living room in ECC 3: $2^{\text {nd }}$ trial (24 to 30 April).

From Table 14 and Figures 5 and 6, we may conclude that: (1) The living room presents very low values of $\mathrm{ACH}$; (2) In the triple room, the peaks of $\mathrm{CO}_{2}$ and TVOC occurred predominantly between 10:00 and 11:00 a.m., followed by a marked decay of $\mathrm{CO}_{2}$. This conjugation of behavior may be the result of cleaning actions, followed by opening windows.

\section{Conclusions and Recommendations}

From the results obtained in both ECC in Viseu, the following conclusions may be drawn: (1) With the exception of the concentration of $\mathrm{CO}_{2}$ in the living room, ECC 1 has an IEQ which is within the regulatory threshold values and standards; (2) In ECC 2, the rooms have high percentages of time with temperatures below regulation standards, and reveal worrying $\mathrm{RH}$ values (with excessive percentages of time with RH values above the recommended maximum limit); (3) In ECC 2, the rooms have excessive periods with temperatures below regulation, and reveal $\mathrm{RH}$ values that raise some concerns (with excessive periods of time with RH values above the recommended maximum limit); (4) With the exception of living room 1, all rooms in ECC 2 had maximum mean values of $\mathrm{CO}_{2}$ which were above the protection threshold; (5) In assessing the thermal comfort by applying the adaptive comfort model 
proposed by LNEC and regarding ECC 2, the rooms are comfortable overall; (6) The ACH were found to be insufficient, with values generally below the required levels for all of the analyzed compartments.

From the results obtained in the ECC in Covilhã, the following conclusions stand out: (1) The RH values in the compartments do not raise concern; (2) The triple room has an excessive percentage of time with below regulation temperatures (perhaps due to opening windows during cleaning actions); (3) The living room has very low ACH values; (4) The triple room has high levels of formaldehyde.

The previous conclusions imply the need for action concerning the heating, maintenance, and ventilation conditions, so that the spaces operate within the appropriate conditions of comfort and air quality.

Author Contributions: Visualization, C.I. and T.F.; Writing—original draft, M.P.; Writing—review \& editing, J.L. and J.V.

Funding: This work is partially supported with Portuguese national funds by FCT—Foundation for Science and Technology within the UID/ECI/04082/2013 project.

Acknowledgments: The authors are grateful to Tiago Freire and Catarina Infante for their contributions resulting from their master's dissertations.

Conflicts of Interest: The authors declare no conflict of interest.

\section{Nomenclature}

$\begin{array}{ll}A & \text { Area of a zone, }\left[\mathrm{m}^{2}\right] \\ \mathrm{ACH} & \text { Air change rate, }\left[\mathrm{h}^{-1}\right] \\ \mathrm{CH}_{2} \mathrm{O} & \text { Formaldehyde } \\ \mathrm{CO}_{2} & \text { Carbon dioxide } \\ \mathrm{E}, \mathrm{NE}, \mathrm{NW}, \mathrm{SE}, & \text { Cardinal points: } \mathrm{E}-\text { East; } \mathrm{NE}-\text { Northeast; NW-Northwest; } \mathrm{SE} \text { - Southeast; } \\ \mathrm{SW}, \mathrm{W} & \text { SW-south-west; } \mathrm{W}-\text { West } \\ \mathrm{ECC} & \text { Elderly Care Centers } \\ \mathrm{HVAC} & \text { Heating, Ventilation, and Air Conditioning } \\ \mathrm{IAQ} & \text { Indoor Air Quality } \\ \mathrm{IEQ} & \text { Indoor Environment Quality } \\ \mathrm{I} / \mathrm{O} & \text { Indoor/Outdoor ratio } \\ \mathrm{LNEC} & \text { National Laboratory for Civil Engineering } \\ \mathrm{Max} & \text { Maximum } \\ \mathrm{Min} & \text { Minimum } \\ M T & \text { Margin of Tolerance } \\ \mathrm{MV} & \text { Mechanical Ventilation } \\ \mathrm{N} & \text { Number of measurement points } \\ \mathrm{n} & \text { Number of values measured to average } 8 \mathrm{~h} \\ \mathrm{NV} & \text { Natural Ventilation } \\ \mathrm{Perc} & \text { Percentage of time that exceeds a certain value } \\ q & \text { Air flow rate, }\left[\mathrm{m}^{3} / \mathrm{h}\right] \\ R H & \text { Relative Humidity, }[-] \\ \mathrm{RR} & \text { Restroom } \\ T & \text { Temperature, }\left[{ }^{\circ} \mathrm{C}\right] \\ T_{\mathrm{mp}} & \text { Running mean outdoor temperature, }\left[{ }^{\circ} \mathrm{C}\right] \\ \mathrm{TVOC} & \text { Total Volatile Organic Compounds } \\ \mathrm{VOC} & \text { Volatile Organic Compound }\end{array}$




$\begin{array}{ll}\text { Greek symbols } & \\ \Delta & \text { Difference } \\ \mu & \text { Mean } \\ \sigma & \text { Standard deviation } \\ \text { Subscripts } & \\ \text { av } & \text { Average (arithmetic mean) } \\ \text { ext } & \text { Referring to the exterior } \\ \text { i } & \text { Referring to a zone } \\ \text { int } & \text { Referring to the interior } \\ \text { Max } & \text { Maximum } \\ \text { RECS } & \text { Referring to Ordinance 353-A/2013 }\end{array}$

\section{References}

1. Frontczak, M.; Wargocki, P. Literature survey on how different factors influence human comfort in indoor environments. Build. Environ. 2011, 46, 922-937. [CrossRef]

2. Mendes, A.; Papoila, A.L.; Carreiro-Martins, P.; Bonassi, S.; Caires, I.; Palmeiro, T.; Aguiar, L.; Pereira, C.; Neves, P.; Mendes, D.; et al. The impact of indoor air quality and contaminants on respiratory health of older people living in long-term care residences in Porto. Age Ageing 2016, 45, 136-142. [CrossRef] [PubMed]

3. Decree-Law No. 118/2013, Energy Performance Regulation for Commercial and Services Buildings (in Portuguese); Ministry of Economy and Employment: Lisbon, Portugal, August 2013. (In Portuguese)

4. INE (Instituto Nacional de Estatística-National Institute of Statistics). Census 2011. In Definitive Results-Portugal; Instituto Nacional de Estatística-National Institute of Statistics: Lisbon, Portugal, 2012. (In Portuguese)

5. Bradshaw, S.A.; Playford, E.D.; Riazi, A. Living well in care homes: A systematic review of qualitative studies. Age Ageing 2012, 41, 429-440. [CrossRef] [PubMed]

6. Mishra, A.K.; Ramgopal, M. Field studies on human thermal comfort-An overview. Build. Environ. 2013, 64, 94-106. [CrossRef]

7. Rupp, R.F.; Vásquez, N.G.; Lamberts, R. A review of human thermal comfort in the built environment. Energy Build. 2015, 105, 178-205. [CrossRef]

8. Mendes, A.; Papoila, A.L.; Carreiro-Martins, P.; Aguiar, L.; Bonassi, S.; Caires, I.; Palmeiro, T.; Ribeiro, Á.S.; Neves, P.; Pereira, C.; et al. The Influence of Thermal Comfort on the Quality of Life of Nursing Home Residents. J. Toxicol. Environ. Health Part A 2017, 80, 729-739. [CrossRef]

9. Van Hoof, J.; Schellen, L.; Soebarto, V.; Wong, J.K.W.; Kazak, J.K. Ten questions concerning thermal comfort and ageing. Build. Environ. 2017, 120,123-133. [CrossRef]

10. Wang, Z.; De Dear, R.; Luo, M.; Lin, B.; He, Y.; Ghahramani, A.; Zhu, Y. Individual difference in thermal comfort: A literature review. Build. Environ. 2018, 138, 181-193. [CrossRef]

11. Huang, Y.C.; Chu, C.L.; Lee, S.N.C.; Lan, S.J.; Hsieh, C.H.; Hsieh, Y.P. Building users' perceptions of importance of indoor environmental quality in long-term care facilities. Build. Environ. 2013, 67, 224-230. [CrossRef]

12. Walgraeve, C.; Demeestere, K.; Dewulf, J.; Van Huffel, K.; Van Langenhove, H. Diffusive sampling of 25 volatile organic compounds in indoor air: Uptake rate determination and application in Flemish homes for the elderly. Atmos. Environ. 2011, 45, 5828-5836. [CrossRef]

13. Almeida-Silva, M.; Wolterbeek, H.; Almeida, S.M. Elderly exposure to indoor air pollutants. Atmos. Environ. 2014, 85, 54-63. [CrossRef]

14. Shao, D.; Du, Y.; Liu, S.; Brunekreef, B.; Meliefste, K.; Zhao, Q.; Chen, J.; Song, X.; Wang, M.; Wang, J.; et al. Cardiorespiratory responses of air filtration: A randomized crossover intervention trial in seniors living in Beijing: Beijing Indoor Air Purifier StudY, BIAPSY. Sci. Total Environ. 2017, 603, 541-549. [CrossRef] [PubMed]

15. Lanzinha, J.; Freire, T.; Alves, A.; Pinto, M. Quality of the Indoor Environment in Elderly Care Centers and Kindergartens in the City of Covilhã -Exploratory Study. In Proceedings of the ICEUBI-International Conference on Engineering 2015, Covilhã, Portugal, 2-4 December 2015. (In Portuguese). 
16. Pinto, M.; Viegas, J.; Freitas, V.; Infante, C. Quality of the Indoor Environment in Elderly Care Cenetrs and Kindergartens in the City of Viseu-Portugal. In Proceedings of the Euro-American Congress REHABEND, Cáceres, Spain, 15-18 May 2018. (In Portuguese).

17. Order 15793-F/2013, Climate Zoning of Portugal; Ministry of Economy and Employment: Lisbon, Portugal, December 2013. (In Portuguese)

18. Ordinance 67/2012, Conditions of Organization, Operation and Installation to Which Residential Structures for Elderly People must Comply; Ministries of Solidarity and Social Security: Lisbon, Portugal, March 2012. (In Portuguese)

19. Ordinance 353-A/2013, Energy Performance Regulation of Commercial and Services Buildings (RECS)_Ventilation and Indoor Air Quality Requirements; Ministries of the Environment, Ordination, Territory and Energy, Health and Solidarity, Employment and Safety Social: Lisbon, Portugal, December 2013. (In Portuguese)

20. Ordinance 349-D/2013, Energy Performance Regulation for Commercial and Services Buildings (RECS)—Design Requirements for New Buildings and Interventions; Ministries of the Environment, Ordination, Territory and Energy and Solidarity, Employment and Social Security: Lisbon, Portugal, December 2013. (In Portuguese)

21. CEN. Indoor Environmental Input Parameters for Design and Assessment of Energy Performance of Buildings. In Addressing Indoor Air Quality, Thermal Environment, Lighting and Acoustic; EN 15251; European Committee for Standardization: Brussels, Belgium, 2007.

22. Social Security Institute. Technical Recommendations for Social Facilities-Elderly Care Centers; Social Security Institute: Lisbon, Portugal, 2007. (In Portuguese)

23. CEN. Ventilation for Buildings. In Design and Dimensioning of Residential Ventilation Systems; CEN/TR 14788; European Committee for Standardization: Brussels, Belgium, 2006.

24. ADENE. Methodology for Periodic IEQ Audits in Existing Services Buildings under the RSECE; Technical Note NT-SCE-02; ADENE—Portuguese Energy Agency: Lisbon, Portugal, 2009. (In Portuguese)

25. Weather Underground. Available online: https://www.wunderground.com (accessed on 9 October 2019).

26. ASTM. Standard Test Method for Determining Air Change in a Single Zone by Means of a Tracer Gas Dilution; ASTM E 741; American Society for Testing and Materials: West Conshohocken, PA, USA, 2011.

27. ASTM. Standard Guide for Using Indoor Carbon Dioxide Concentrations to Evaluate Indoor Air Quality and Ventilation; ASTM D 6245-12; American Society for Testing and Materials: West Conshohocken, PA, USA, 2012.

28. Matias, L. Development of an Adaptive Model to Define Thermal Comfort Conditions in Portugal. Ph.D. Thesis, IST-Instituto Superior Técnico, Lisbon, Portugal, 2010. (In Portuguese).

29. ASHRAE. Thermal Environmental Conditions for Human Occupancy; Ansi/Ashrae Standard 55; American Society of Heating, Refrigeration and Air-Conditioning Engineers: Atlanta, GA, USA, 2004.

30. CEN. Ergonomics of the Thermal Environment-Analytical Determination and Interpretation of Thermal Comfort Using Calculation of the PMV and PPD Indices and Local Thermal Comfort criteria (ISO 7730:2005); EN ISO 7730; European Committee for Standardization: Brussels, Belgium, 2005.

(C) 2019 by the authors. Licensee MDPI, Basel, Switzerland. This article is an open access article distributed under the terms and conditions of the Creative Commons Attribution (CC BY) license (http://creativecommons.org/licenses/by/4.0/). 